\title{
Fuelwood harvest, management and regeneration of two community forests in Central Nepal
}

\author{
Bharat Babu Shrestha \\ Central Department of Botany, Tribhuvan University, Kathmandu, NEPAL \\ For correspondence, E-mail: bhabashre@yahoo.com
}

\begin{abstract}
From J uly to December 2003 we studied the impact of forest resource use and management practices on community structure and regeneration of locally managed Shorea robusta (sal) forest in the mid-hills of central Nepal. We carried out a household survey in two villages (Namjung village of Gorkha and Khari village of Dhading district), and studied the community structure and regeneration of important multipurpose tree species (Shorea robusta Gaertn. and Schima wallichii (DC.) Korth.) in community forests. Dependency on forests has been decreasing due to limited access to resources, decrease in cattle number and the cultivation of more fuelwood and fodder trees in non-forested land. Nonetheless, forests remain the major source of fuelwood, supplying $63 \%$ of the total. Alternative energy sources (biogas and solar cell) were not significant at the time of our study. S. robusta was the dominant tree in both forests, with high relative density (74\%) in Namjung forest (NF) and $50 \%$ in Khari forest (KF); its importance value index (IVI) was 171 in NF and 152 in KF. Tree density of sal in NF was the highest (909 tree ha-1 ${ }^{-1}$ among the reported values in references for the same species. Both forests had comparatively low species diversity (1.09 in NF and $1.30 \mathrm{in} \mathrm{KF);} \mathrm{local} \mathrm{management} \mathrm{appears} \mathrm{to} \mathrm{contribute} \mathrm{to} \mathrm{reduced} \mathrm{diversity.} \mathrm{Regeneration} \mathrm{of} \mathrm{sal} \mathrm{was} \mathrm{sustainable} \mathrm{and} \mathrm{fairly} \mathrm{high,}$ with a typical reverse-J -shaped size class diagram (in NF), a good predictor of mono-dominant sal forest. Regeneration of $S$. wallichii was unsustainable in both forests.
\end{abstract}

Key words: Schima wallichii, Shorea robusta, size class diagram, species diversity

Himalayan J ournal of Sciences 3(5): 75-80, 2005

Available online at: www.himjsci.com
Received: 15 | uly 2004

Accepted after revision: 23 May 2005
Copyright@ 2005 by Himalayan Association for the Advancement of Science (HimAAS)
Rural people depend on forest resources for their energy needs, fodder, timber and employment. Fuelwood is one of the most important forest resources, accounting for an estimated $7 \%$ of the world's total energy supply (FAO 1999). It plays a major role (80\%) in the energy supply of Nepal, and its consumption is increasing by $2.0 \%$ per annum (Shrestha 2000). Fuelwood has the potential to be an attractive renewable source of energy because it is $\mathrm{CO}_{2}$-neutral and economically affordable for rural people. Fuelwood consumption is not and will not be the main cause of deforestation; non-forest land is and will continue to be the main source of fuelwood (RWEDP 1997). However, some people believe that the demand for fuelwood in developing countries can only be met by overexploitation of forests, which is the major cause of deforestation (Schulte-Bisping et al. 1999). To resolve these conflicting views, we need adequate reliable data, which, in the case of Nepal, is lacking (Shrestha 2002).

Forested areas, a major source of fuelwood, are decreasing at the rate of $1.8 \%$ per annum in Nepal (FAO 2001) and all five Development Regions suffer fuelwood deficits (RWEDP 1997). The impact of fuelwood collection on forests has been controversial and its role in rural livelihoods and deforestation the subject of considerable debate. The practice of using a few selected species for fuelwood and absolute conservation of dominant species in community-managed forests may affect the regeneration process and community structure of forests. The impact of fuelwood collection on forests is largely determined by the extent of peoples' relative dependency on forested and non-forested lands for fuelwood.
To elucidate the relationship between fuelwood consumption and forest structure, the use patterns of fuelwood in two villages of central Nepal and their forests were studied with the following specific objectives: 1) to quantify the use of forest resources (fuelwood and fodder) by local people; 2) to identify the relative importance of forest and non-forest sources of fuelwood and fodder; and 3) to assess the impact of local management on forest structure and regeneration.

\section{Materials and methods}

Study site

We surveyed fuelwood consumption in two mid-hill villages of central Nepal: Majhitar of Namjung Village Development Committee (VDC), Gorkha district, and Kumaltari of Khari VDC, Dhading district; we refer to these as NV and KV, respectivly. There were 78 households in NV and 116 in KV; about $90 \%$ households were engaged in subsistence agriculture. They obtained timber from the forest, but fuelwood and fodder were obtained from both farmland and forest.

We studied vegetation structure and regeneration in Jhakreko Pakha, or "Namjung forest"(NF) near NV and Devisthan Community Forest, or "Khari forest" (KF) near KV. NF lies on the south-east face of a hill with slope $60^{\circ}$ at $27^{\circ} 56^{\prime}$ $\mathrm{N}$, 84 $43^{\circ}$ ' E, alt. 500-800m; KF lies on the north-west face of a hill with slope $70^{\circ}$ at $27^{\circ} 56^{\prime} \mathrm{N}, 8^{\circ}{ }^{\circ} 44^{\prime}$ E, alt. 450-1000m. NF has been protected for the past 15 years, and the use of Shorea robusta (sal) in any form has been prohibited. Limited timber harvesting for non-commercial purpose was permissible, provided royalties were paid. KF has been protected for the 
last four years, and the use of sal and Terminalia alata in any form were completely prohibited. The harvest of Schima wallichii and Castanopsis indica for non-commercial purposes were allowed in KF. Sal is the dominant tree species in both forests; major associated species are S. wallichii and Terminalia alata in NF and S. wallichii, C. indica and Engelhardia spicata in KF. Grazing was common in both forests. Forest fires were less common in recent years but were more frequent until 45 years back. Fallen branches, dead trees and live individuals of shrub species were collected for fuelwood. In KF the practice of thinning has been implemented at limited areas.

\section{Sampling and data analysis}

\section{Household survey}

We collected field data during October 2003. Using structured questionnaires, we surveyed 12 households (representing $>10 \%$ of total) in each village. All ethnic groups and economic classes were proportionately represented in the samples. The survey focused particularly on the supply of fuelwood and fodder from farmland and forestland. The woody part of fodder left over by animals is also used as fuelwood; thus it was included in our survey. We determined the number of domestic animals per capita, per capita fuelwood consumption (kg/person/year), and proportion of total supply of tree (woody) fodder and fuelwood derived from forest and farmland.

\section{Results}

Household survey

The average family size was six persons and the average number of domestic animals 12 per family in NF, and seven and 10.5 respectively in KF. Forest resources were being used for non-commercial and domestic purpose. The dependency of local people on forests for fuelwood and fodder had decreased in $50 \%$ of households, remained the same in $33 \%$ and increased in $17 \%$ as compared to 10 years prior to our study. The decrease in dependency, where it occurred, was due to reduced supply, restriction in use, reduced numbers of cattle, and installment of biogas and solar power facilities. Increased use of forest resources was related to increase in family size, increase in number of cattle, and decreased supply of fuelwood and fodder from farm land. The four preferred species for fuelwood were Schima wallichii, Lagerstroemia parviflora, Adina cordifolia and sal. People depended more on forest (63\% of total supply) than farmland $(37 \%)$ for fuelwood (Table 1). Per capita fuelwood consumption was $541 / \mathrm{kg} /$ person/year in NV and $388 \mathrm{~kg} /$ person/year in KV. Fuelwood was used for cooking (both for humans and animals) and for space heating. Generally, fuelwood was cut during February-March, sun-dried for a few weeks and stored in a dry place for use throughout the year. $95 \%$ of households used fuelwood for cooking and space heating, and $92 \%$ used kerosene

\section{Forest sampling}

In view of the heterogeneous landscape, we chose to use relatively small quadrats of $10 \mathrm{~m} \times 10 \mathrm{~m}$. Each forest was divided vertically into halves and in each a single quadrat was laid out at altitude increments of $50 \mathrm{~m}$. We studied twelve quadrats in NF from 500 to 750 masl and 17 quadrats in KF from 500 to 950 masl. In KF a single quadrat was studied at each of 500, 550 and 950 masl due to the physical inaccessibility of potential sampling sites. We measured diameter at breast height (dbh, at $137 \mathrm{~cm}$ height), of all trees $(\mathrm{dbh} \geq 10 \mathrm{~cm})$, and we counted the number of saplings ( $\geq 20 \mathrm{~cm}$ height and $<10 \mathrm{~cm} \mathrm{dbh}$ ) and individuals of shrub species. We did not record seedlings or herbs. We identified plants with the help of standard references (Stainton 1997, Polunin and Stainton 2000). The nomenclature follows DPR (2001). We calculated density $\left(\mathrm{ha}^{-1}\right)$, frequency (\%), and basal area $\left(\mathrm{m}^{2} \cdot \mathrm{ha}^{-1}\right)$ of trees, as well as their relative values. Importance Value Index (IVI) was calculated as the sum of relative values of density, frequency and dominance (Zobel et al. 1987). Tree density and dbh classes (10-15 cm, 15-20 $\mathrm{cm}, 20-25 \mathrm{~cm}$, etc.) of sal and S. wallichii were used to develop a size-class distribution diagram. Simpson's index of dominance (C) and the Shannon-Wiener index of species diversity ( $\left.H^{\prime}\right)$ were calculated following Barbour et al. (1999). We compared the species diversity of the two forests (tree layer) using the Student t-test following Jayaraman (2000).
TABLE 1. Comparison of per capita domestic animals, and supply and types of fodder and fuel wood in two villages

\begin{tabular}{|c|c|c|c|c|c|c|c|c|}
\hline \multirow[t]{2}{*}{ Village } & \multirow{2}{*}{$\begin{array}{c}\text { Per } \\
\text { capita } \\
\text { domestic } \\
\text { animals }\end{array}$} & \multicolumn{2}{|c|}{$\begin{array}{l}\text { Fodder type } \\
(\%)\end{array}$} & \multicolumn{2}{|c|}{$\begin{array}{c}\text { Supply of tree } \\
\text { fodder (\%) }\end{array}$} & \multirow{2}{*}{$\begin{array}{l}\text { Per capita } \\
\text { fuelwood } \\
\text { consumption } \\
\text { (kg/person/yr) }\end{array}$} & \multicolumn{2}{|c|}{$\begin{array}{l}\text { Supply of } \\
\text { fuelwood (\%) }\end{array}$} \\
\hline & & Grass & Tree & Forest & $\begin{array}{l}\text { Agri. } \\
\text { land }\end{array}$ & & Forest & Farm land \\
\hline Namjung & 2.15 & 50 & 50 & 39 & 61 & 541 & 58 & 42 \\
\hline Khari & 1.63 & 48 & 52 & 29 & 71 & 388 & 68 & 32 \\
\hline Average & 1.89 & 49 & 51 & 34 & 66 & 464.5 & 63 & 37 \\
\hline
\end{tabular}

TABLE 2. Density $\left(\mathrm{D}, \mathrm{ha} \mathrm{H}^{-1}\right)$, Basal Area $\left(\mathrm{BA}, \mathrm{m}^{2} \cdot \mathrm{ha}^{-1}\right)$ and Importance Value Index (IVI) of tree species at Namjung Forest (NF) and Khari Forest (KF)

\begin{tabular}{lcccccc}
\hline \multirow{2}{*}{ Name } & \multicolumn{3}{c}{ Namjung Forest (NF) } & \multicolumn{3}{c}{ Khari Forest (KF) } \\
\cline { 2 - 8 } & D & BA & M & D & BA & M \\
\hline Shorea robusta Gaertn. & 909 & 30.97 & 171.23 & 125 & 10.88 & 151.61 \\
\hline Schima wallichii (DC.) Korth. & 108 & 8.27 & 45.63 & 84 & 3.5 & 92.21 \\
\hline Semecarpus anacardium L.f. & 67 & 1.86 & 26.01 & 6 & 0.078 & 7.51 \\
\hline Terminalia alata Herne ex Roth & 25 & 0.48 & 10.36 & - & - & - \\
\hline Syzygium cumini (L.) Skeels & 17 & 0.49 & 7.31 & 6 & 0.078 & 7.51 \\
\hline Lagerstroemia parviflora Roxb. & 17 & 0.22 & 6.69 & - & - & - \\
\hline Engelhardia spicata Leschen. ex Blume & 17 & 0.48 & 4.69 & 12 & 0.127 & 14.85 \\
\hline Cleistocalyx operculatus (Roxb.) Merr. & 17 & 0.25 & 6.78 & 6 & 0.047 & 7.31 \\
\& Perry & & & & & & \\
\hline Mangifera indica Linn. & 17 & 2.07 & 10.65 & 6 & 0.73 & 11.72 \\
\hline Wendlandia sp. & 17 & 0.19 & 4.08 & 6 & 0.047 & 7.31 \\
\hline Adina cordifolia (Wild. ex Roxb.) Benth. & 8 & 0.15 & 3.26 & - & - & - \\
\& Hook. f. ex Brandis & & & & & & \\
\hline Castanopsis indica (Roxb.) Miq. & 8 & 0.13 & 3.21 & - & - & - \\
\hline Total & 1227 & 45.56 & 299.9 & 251 & 15.48 & 300 \\
\hline
\end{tabular}




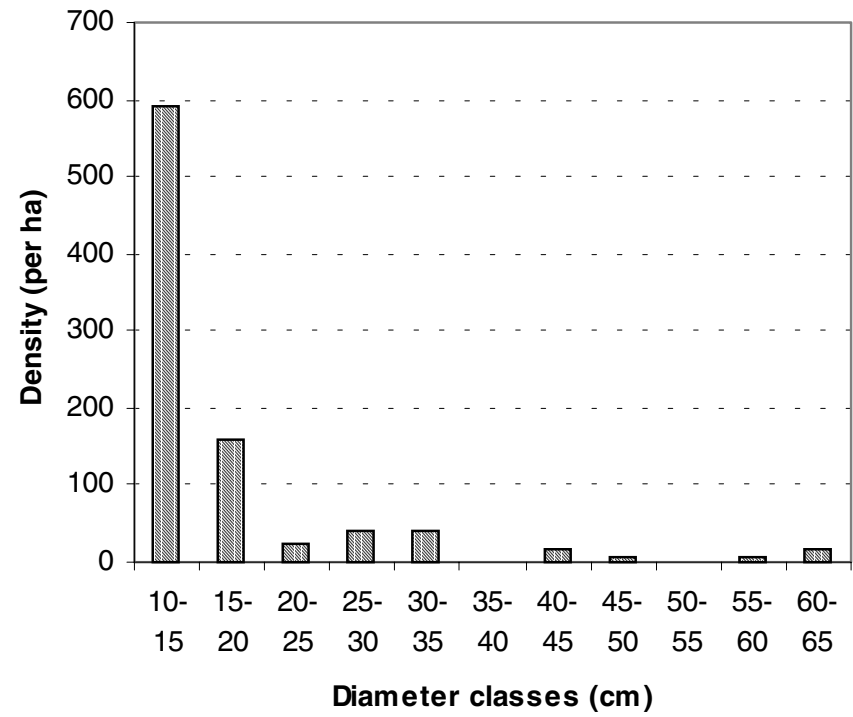

FIGURE 1. Density of different diameter classes of trees of S. robusta in Namjung forest

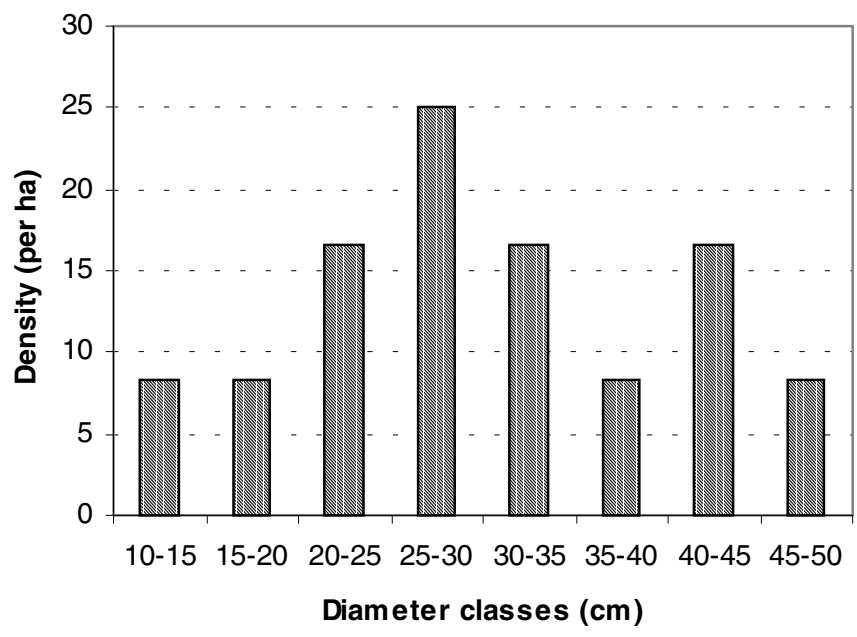

FIGURE 2 Density of different diameter classes of trees of S. wallichii in Namjung forest

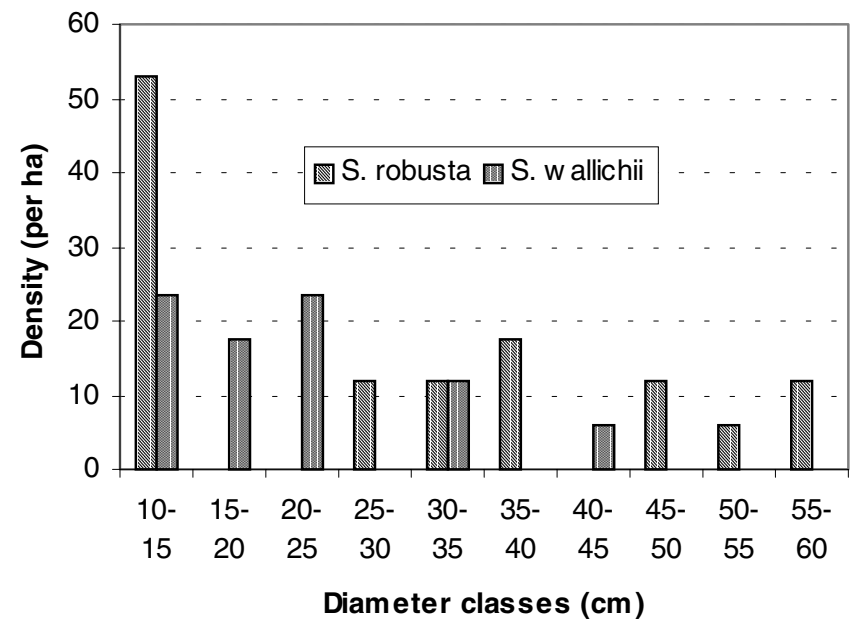

FIGURE 3 Density of different diameter classes of trees of S. robusta and S. wallichii in Khari forest for lighting. Most of the households used the "improved stove," which significantly reduced fuelwood consumption. Alternative energy sources such as biogas and solar panels were not widespread: only $5 \%$ of the households used biogas and $8 \%$ solar power. Many households were facing problems in collecting fuelwood, but they had not installed biogas due to economic constraints and lack of technical know-how. Most, however, believed that the used of biogas was a good idea.

Every household kept domestic animals such as cow, buffalo, and goat. Per capita ownership of domestic animals (0.78) was higher than the national rate (CBS 2002). Due to the highly accidented landscape, buffaloes were kept at home on a permanent basis, while cows and goats were brought to nearby forest and grassland for grazing. As fodder, villagers used grasses (non-woody herbaceous fodder plants) and tree fodder in nearly equal amounts (Table 1). Farmland was the major source of tree fodder ( $66 \%$ of total supply). In the past, a greater proportion of fodder had been derived from the forest. Sal was the preferred tree for fodder, but use of this species as fodder was restricted after the inception of community management. People could harvest sal only by thinning in specified months.

Besides timber, fuelwood and fodder, people also used the leafy branches of Castanopsis indica for roofing, small trees of Schima wallichii, Holoptelea integrifolia and Adina cordifolia as support (locally called thakra) in growing vegetables, medium sized trees of $S$. wallichii and sal for making plows, and leafy branches of Engelhardia spicata and S. wallichii as green manure and mulch. Black dye extracted from the bark of mature sal was used for painting doors, windows and verandas. Most of villagers were in favor of the current conservation practices, but some wanted more access to fodder plants such as sal.

\section{Forests}

Both forests were dominated by sal, with $S$. wallichii as codominant. In NF 12 species were recorded at tree stage (Table 2). Density ranged from 8 to $909 \mathrm{ha}^{-1}$, and basal area ranged from 0.13 to $30.97 \mathrm{~m}^{2} \cdot \mathrm{ha}^{-1}$. The total basal area of all tree species was $45.56 \mathrm{~m}^{2} \cdot \mathrm{ha}^{-1}$. Sal had the highest IVI (171), which was nearly four times higher than the IVI of the co-dominant species, S wallichii (46). Sal was fairly regenerating with a typical reverseJ-shaped size-class distribution (Figure 1). The sapling-to-tree ratio was $14: 1$, with sapling density at $12,642 \mathrm{ha}^{-1}$. The regeneration of $S$. wallichii was poor, as was reflected in the bell-shaped size-class distribution curve (Figure 2). The saplingto-tree ratio was 1.23:1, and the sapling density was $133 \mathrm{ha}^{-1}$. In Khari Forest (KF), eight species were recorded in tree stage $(\mathrm{dbh}>10 \mathrm{~cm}$, Table 2). The total basal area of all trees was 15.48 $\mathrm{m}^{2} \cdot \mathrm{ha}^{-1}$. KF trees are larger than NF, with average $\mathrm{dbh}$ of $30 \mathrm{~cm}$ $(\mathrm{N}=19)$ and open canopy. The relative density of sal was $50 \%$ whereas that of $S$. wallichii, an important associate species, was $33.46 \%$. Sal regeneration was discontinuous, with individuals not represented in dbh classes of 15-20 cm, 20-25 $\mathrm{cm}$ and 40-45 cm (Figure 3). Sapling density was $6383 \mathrm{ha}^{-1}$ (Table 3), and sapling-to-tree ratio was 51:1. S. wallichii appeared to be regenerating, but its density was very low (Table 2 ). Two dbh classes were absent from the population of $S$. walichii (Figure 3). Sapling density was $505 \mathrm{ha}^{-1}$ and saplingto-tree ratio was 6:1. Seven tree species in NF and eleven in KF were represented only at the sapling stage (Table 3 ). There were six shrub species in NF and nine in KF (Table 4).

Forest fire, grazing and lopping were important pressures on both forests. Fire damage was followed by termite 
infestation. We observed saplings that had fallen due to fire damage and subsequent termite infestation. In KF tree felling was very frequent before the beginning of community management. Stumps were present in $65 \%$ of quadrats, up to five stumps in a single sample $(10 \mathrm{~m} \times 10 \mathrm{~m})$. A total of 31 stumps were recorded (sal 21, Schima wallichii 7, Castanopsis indica 1, Wendlandia 1 and Lyonia ovalifolia 1 ). The total density of stumps was $182 \mathrm{ha}^{-1}$, which was more than the density of dominant tree (sal, 125 ha" $^{\prime 1}$ ).

Tree species richness was higher in NF than in KF (Table 5). The contribution of a single dominant species (sal) was much greater than other associated species (Table 2). Therefore, NF had a higher Simpson's index (C) but a lower Shannon-Wiener index (H') than KF. Despite the small number of tree species, KF had a significantly higher species diversity $(\mathrm{t}$ $=2.788, \mathrm{df}=470, \mathrm{p}<0.01$ ) due to high species evenness. KF also had high species diversity for shrubs.

\section{Discussion}

Use of forest resources

People in the study area depended on forest resources for their subsistence livelihood, primarily as a source of fuelwood and fodder. The contribution of these two forest resources (fuelwood and fodder) to Nepal's national income is significant (Katila 1995). A community forest, if managed on an equitable and sustainable basis, can satisfy these basic needs and improve the livelihood of rural people in Nepal (Maharjan 2003).

There was a wide difference between in two villages studied in per capita fuelwood consumption (Table 1). The higher rate in NV was due to the greater number of domestic animals per capita. A significant amount of fuelwood was consumed in cooking animal feed. People used to fell trees for fuel wood but in recent times this practice has been prohibited in the community forest. Woody parts of fodder not consumed by animals were an important source of fuelwood from the agricultural sector. Old and dying fodder trees on agricultural land were harvested for fuelwood. The amount of fuelwood derived from the forest had been decreasing, and people had been spending more time collecting fuelwood. People had been learning to use agricultural residues as fuel, and improved stoves had significantly reduced fuel wood consumption, but the forest was still the major source, supplying $63 \%$ of the total fuelwood (Table 1).

In comparison to the situation ten years ago, dependency on the forest for fodder and fuelwood has decreased in $50 \%$ of households. Extraction of these resources from the forest has decreased and the use of several preferred species has been restricted. This has forced people to grow more fodder trees on their private land, and to make better use of agricultural residues (e.g., the woody parts of fodder), which had not used until few decades back. Most of the villagers were aware that growing trees on agricultural land was useful for soil conservation and as a convenient source of fodder and fuelwood; nevertheless, due to the shortage of crop land, the practice is not common. Concerted efforts by government agencies and non-government organizations to provide support services integrating indigenous knowledge may motivate people to grow more trees on agricultural land (Paudel 2003), thereby reducing pressure on the forest.

S. wallichii was the preferred tree for fuelwood. Regeneration of this species was very poor and discontinuous in both forests (Figure 2 and 3, Table 3); this may be directly attributed to fuelwood extraction Unfortunately, use of fossil
TABLE 3. Sapling density $\left(\mathrm{ha}^{-1}\right)$ of trees in Namjung forest (NF) and Khari forest (KF)

\begin{tabular}{lcc}
\hline \multirow{2}{*}{ Name } & \multicolumn{2}{c}{ Density } \\
\cline { 2 - 3 } & NF & KF \\
\hline Adina cordifolia (Wild. ex Roxb.) Benth. \& & 16 & - \\
Hook. f. ex Brandis & & \\
\hline Antidesma acidum Retz.* & - & 12 \\
\hline Bridelia retusa (L.) Spreng. ${ }^{*}$ & - & 6 \\
\hline Callicarpa vestita Wall. ex C.B. Clarke* & 8 & 6 \\
\hline Castanopsis indica (Roxb.) Miq. & 16 & 206 \\
\hline Cleistocalyx operculatus (Roxb.) Merr. \& Perry & 142 & 325 \\
\hline Engelhardia spicata Leschen. ex Blume & 42 & 82 \\
\hline Holoptelea integrifolia (Roxb.) Planch.* & 142 & 200 \\
\hline Kummo*\# & 24 & 71 \\
\hline Lagerstroemia parviflora Roxb. & 92 & $59 *$ \\
\hline Lyonia ovalifolia (Wall.) Drude* & 8 & 224 \\
\hline Mangifera indica Linn. & 92 & 35 \\
\hline Phyllanthus emblica Linn.* & 242 & 29 \\
\hline Schima wallichii (DC.) Korth. & 133 & 505 \\
\hline Semecarpus anacardium L.f. & 183 & 347 \\
\hline Shorea robusta Gaertn. & 12642 & 6383 \\
\hline Syzygium cumini (L.) Skeels & 84 & 12 \\
\hline Terminalia alata Herne ex Roth & 160 & $71 *$ \\
\hline Terminalia belerica (Gaertn.) Roxb.* & 16 & - \\
\hline Terminalia chebula Retz.* & 8 & 6 \\
\hline Wendlandia sp. & 317 & 706 \\
\hline Total & 14367 & 9285 \\
\hline$*$ Tree species represented only by saplngs; & & \\
\hline
\end{tabular}

* Tree species represented only by saplings; \# Local name

TABLE 4. Density (ha ${ }^{-1}$ ) of Shrubs in Namjung forest (NF) and Khari forest (KF)

\begin{tabular}{lcc}
\hline \multirow{2}{*}{ Name } & \multicolumn{2}{c}{ Density } \\
\cline { 2 - 3 } & NF & KF \\
\hline Ardisia solanacea Roxb. & - & 247 \\
\hline Eurya acuminata DC. & - & 35 \\
\hline Holarrhena pubescens (Buch.-Ham.) & 36 & - \\
Wall. ex D.Don & & \\
\hline Inula cappa Wall. ex DC. & - & 212 \\
\hline Maesa macrophylla (Wall.) A. DC & - & 53 \\
\hline Melastoma normale D.Don & 9 & 167 \\
\hline Rhus javanica Linn. & 318 & 188 \\
\hline Swida oblonga (Wall.) Sojak & 191 & 935 \\
\hline Woodfordia fruticosa (L.) Kurz. & 291 & 576 \\
\hline Zizyphus sp. & 9 & 47 \\
\hline Total & 854 & 2458 \\
\hline
\end{tabular}

TABLE 5. Simpson's index (C) of dominance and Shannon-Wiener index $\left(\mathrm{H}^{\prime}\right)$ of species diversity for Namjung forest (NF) and Khari forests (KF)

\begin{tabular}{ccccc}
\hline Plant habit & \multicolumn{2}{c}{$\mathbf{C}$} & \multicolumn{2}{c}{$\mathbf{H}^{\prime}$} \\
\cline { 2 - 5 } & $\mathbf{N F}$ & $\mathbf{K F}$ & $\mathbf{N F}$ & KF \\
\hline Tree & 0.55 & 0.36 & 1.09 & 1.30 \\
\hline Shrub & 0.30 & 0.22 & 1.28 & 1.98 \\
\hline
\end{tabular}


fuels by rural people is neither economically feasible nor environmentally friendly. Efficient use of available agricultural residues through technical innovations may be a better solution to the problem of diminishing fuelwood supply. An improved wood energy system might help to mitigate climate change by reducing reliance on fossil fuels and sequestering $\mathrm{CO}_{2}$ (the most important greenhouse gas) in growing trees (Heruela 2003). It would also result in significant foreign exchange saving for countries like Nepal. Alternatively, popularization of biogas and solar cells may reduce dependency on fuelwood.

\section{Forest structure}

The community structures of NF and KF were quite distinct in term of the contribution of dominant species and basal area cover. These two forests had an equal number (19) of tree species but seven species in NF and 11 in KF were found only in sapling stage (Table 3). Most of the species represented only in sapling stage do not yield high quality timber when they mature to tree, nor are they preferred for fodder or fuelwood. Since the initiation of community management, however, pressure on these species as a source of fodder and fuel wood has increased due to restrictions on the use of the preferred tree species.

The number of species forming tree canopy was high in NF but single dominant species (sal) had very high density and relative density (Table 2); therefore NF is developing into mono-dominant sal forest. Density of sal was higher than values reported for sal anywhere else in Nepal (Giri et al. 1999) or India (Negi et al. 2002). Basal area of sal $\left(30.97 \mathrm{~m}^{2} \times \mathrm{ha}^{-1}\right)$ and total basal area $\left(45.56 \mathrm{~m}^{2} \times \mathrm{ha}^{-1}\right)$ of all trees were also higher than in a Terai sal forest (Giri et al. 1999). However, individual sal trees were small, with average dbh of $18 \mathrm{~cm}(\mathrm{~N}=113)$. A mono-dominant sal forest (relative density $>70 \%$ ) is particularly susceptible to the sal borer (Hoplocerambyx spinicornis) due to lack of ecological balance (Negi et al. 2002). We would recommend that the management of this forest be modified: thinning of sal and restraint in exploitation of other species such as S. wallichii can prevent the forest from progressing toward monodominant type.

Although sal was the dominant tree species in KF, its density $\left(125 \mathrm{ha}^{-1}\right)$ was very low in comparison to Giri et al. (1999) and Negi et al. (2002) and distribution was not uniform (frequency 41\%). However, sapling density (Table 3) and sapling-to-tree ratio (51:1) for sal was high as compared to NF (14:1), indicating high regeneration potential. This forest may also develop into mono-dominant sal forest if the management practice is not changed.

Density and species richness of the shrub layer was higher in KF than in NF (Table 4), which appears to be due to the open canopy condition in former. Intense disturbance and excessive felling of trees in the past resulted in open canopy in $\mathrm{KF}$, allowing the growth of large number of shrub species. Similarly, recent conservation efforts have resulted in a rapid increase in sapling density (Table 3) of tree species.

Despite the higher tree species richness in NF (Table 2), it has a lower species diversity (Table 5). The contribution to forest community of a single dominant species (sal) was very high while other species became rare. It appears that associated species have been over-exploited for sal conservation. Fifteen years of local management have preserved a forest but disturbed the natural ecosystem. KF, which has been conserved for four years, had a significantly higher species diversity $(p<0.01)$ due to higher species evenness (i.e. more uniform distribution of relative density among the species). The decrease in species diversity due to local extinction of less common species makes the ecosystem less stable. Ecosystem stability cannot be ensured merely by high species diversity, but diversity is certainly a prerequisite for ecosystem stability (Naeem and Li 1997, McCann 2000). Both of these forests had a lower species diversity than natural sal forests studied in India (e.g., Pandey and Shukla 1999, Shankar 2001). Therefore, conservation of species diversity should also be a priority of community forest management.

\section{Regeneration}

The reverse-J-shaped size-class distribution (Figure 1) of sal in the studied forests indicates sustainable regeneration (Vetaas 2000). The absence of certain larger dbh classes from the population was due to severe disturbance in the past before conservation. Forest conservation greatly increased the sapling density (Table 3) and sapling-to-tree ratio. Thus sal will continue to be the dominant species of these forests in future if the same management practice prevail. However, $S$. wallichii, the most important associate of sal in this forest, had a bell-shaped sizeclass distribution (Figure 2), which indicates the lack of sustainable regeneration (Vetaas 2000). Sapling density (Table 4), and sapling-to-tree ratios were very low. S. wallichii was the most preferred species for fuelwood; with the use of sal restricted, $S$. wallichii was also being harvested to meet timber needs. Finally, regeneration by coppice is weaker in S. wallichii than in sal. The combined effect of all these anthropogenic disturbances and inherent behavior has hampered the regeneration S. wallichii in NF.

The size-class distribution curve of sal in KF resembled neither a reversed J nor a bell shape (Figure 3 ). Since the lowest diameter class had the highest density, the regeneration potential was high, but regeneration had not been continuous in the past. The poor representation of two successive small-dbh classes might have been due to intense forest fires in successive years, which prevented seedling establishment and sapling recruitment and resulted in the discontinuous population structure of sal in KF. Recent management practice has rapidly increased the sapling density (Table 3). Within a few decades this forest may change into a dense forest with closed canopy. The canopy closure occurs at an exponential rate and the time required for full canopy closure depends on the type and magnitude of disturbance and on the species involved in regeneration (Valverde and Silvertown 1997); it may range from 8 to 40 years for tropical and temperate forest. The status of $S$. wallichii in KF was better than that in NF, with high sampling density (Table 3) and sapling-to-tree ratio, and good representation of small trees in the population (Figure 3). The forest had several moist sites, which are suitable for growth of S. wallichii. The open canopy also promoted sapling recruitment and tree growth at early stage.

The regeneration potential of sal was fairly high in both these forests, and regeneration was continuous in NF. The density of sapling and small trees has increased rapidly in recent years as the effect of community management. In Nepal, sustainable regeneration of sal has been reported from both Terai (Rautiainen 1996 and Giri et al. 1999) and the hills (Rai et al. 1999). However, regeneration was not sustainable in natural dense forest with a high density of larger trees (Rai et al. 1999). Sal has been facing a serious threat to its existence in the tropical and subtropical belts of India due to infestation by the sal borer (Hoplocerambyx spinicornis) and also to moisture stress caused by the combined effects of intensive grazing, 
repeated fire, lopping and indiscriminate harvesting (Negi et al. 2002). Mortality rates of seedling and smaller trees are high under these situations. The problems of stem borer and heart and root rot diseases have also been reported from a leasehold forest in Rupandehi of Nepal (Hartz 1999). Although the extent of damage was not serious, damage frequency and distribution have been increasing and that trend is likely to deteriorate in the future. The problem will be more serious if it spreads into community forests, which are evolving toward monodominance due to excessive removal of the unprotected plant species. As noted before, mono-dominant sal forest is more susceptible to sal borer attack (Negi et al. 2002) probably due to local extinction of borer's natural predators. Similarly, largescale defoliation (>90\%) of young sal leaves by red ants has been observed in a few community managed sal forests in Gorkha (Nepal) (personal observation, June 2005). This, obviously, has a negative impact on the growth and survival of individual trees and on the sustainability of the forest. However the community structure and insect-plant interactions in these forests have not been studied.

\section{Conclusions}

In comparison to the situation ten years ago, dependency on forests for fodder and fuelwood has decreased in $50 \%$ of households due to increased supply from non-forest lands, decrease in cattle number, and limited access to forest. Although fuelwood has been extracted from both forest and non-forest lands, forests were the major source $(63 \%)$. Limited access to forest has encouraged people to use fuelwood from non-forest sources more efficiently. The trend showed that with technological innovations in fuelwood use, alternative energy (biogas and solar cell), and growth of more trees in non-forest lands, dependency on forests for fuelwood will decrease in the future. The regeneration potential of sal (Shorea robusta Gaertn.) was fairly high in both community forests, but community management in the NF and KF appears to be non-sustainable, as the species diversity has been decreasing. The present management practices may lead to the development of monodominant sal forests with insignificant contributions from other associated species. Schima wallichii, a multiple use plant, has become the most preferred tree species for fuelwood. Regeneration of this species was not sustainable and it has been overexploited for the sake of sal conservation.

\section{Acknowledgements}

Financial support from the University Grant Commission (Kathmandu, Nepal) through a Mini Research Grant is gratefully acknowledged. I thank Giriraj Tripathi (Amrit Science Campus, Kathmandu) for valuable assistance during project development; PK Jha and HD Lekhak (Central Dept. of Botany, Tribhuvan University, Kathmandu) for critical comments on the work; NPS Duwadee (National Integrated College, Kathmandu) for helping in plant identification; and D Shrestha, DB Shrestha, KK Shrestha and RK Shrestha for field assistance. Thanks are also due to all respondents to our household survey. I also thank the authorities of both community forests for granting permission to work in the forest.

\section{References}

Barbour MG, JH Burk, WD Pitts, FS Gilliam and MW Schwartz. 1999. Terrestrial plant Ecology, 3rd ed. California: Benjamin/Cummings, an imprint of Addison Wesley Longman, Inc. $649 \mathrm{p}$

CBS 2002. Statistical pocket book. Kathmandu: Central Bureau of Statistics (CBS), National Planning Commission Secretariat, HMGN. 301 p
DPR. 2001. Flowering plants of Nepal (Phanerogams). Kathmandu: Departmant of Plant Resources, Ministry of Forest and Soil Conservation. $399 \mathrm{p}$

FAO. 1999. State of the world forests. Rome: Food and Agriculture Organization (FAO). $146 \mathrm{p}$

FAO. 2001. State of the world forests. Rome: Food and Agriculture Organization (FAO). $181 \mathrm{p}$

Giri A, B Aryal, B Bhattarai, SK Ghimire, KK Shrestha and PK Jha. 1999. Vegetaion composition, biomass production and regeneration in Shorea robusta forests in the Royal Bardia National Park, Nepal. Nepal Journal of Science and Technology 1: 47-56

Hartz T. 1999. Sal forest management and silvicultural operations. In: Mathema P, IC Dutta, MK Bala and SN Adhikari (eds), Sustainable forest management. Proceeding of international seminar, 1998 Aug 31-Sept 2; Pokhara. Pokhara (Nepal): Institute of Forestry, Tribhuvan University. p 39-44

Heruela CS. 2003. Wood energy information analysis in Asia. Bangkok (Thailand): EC-FAO Partnership Programme, FAO Regional Office for Asia and the Pacific. $98 \mathrm{p}$

Jayaraman K. 2000. A Statistical Manual for Forestry Research. Bangkok (Thailand): Forestry Research Support Programme for Asia and the Pacific (FORSPA), Food and Agriculture Organization (FAO). FROSPAFAO Publication. $340 \mathrm{p}$

Katila M. 1995. Accounting for market and non-market production of timber, fuelwood and fodder in the national income accounting framework: a case study. Banko Janakari 5(1): 18-23

Maharjan MR. 2003. Policy implications for equitable cost and benefit sharing in community forestry in Nepal. Banko Janakari 13(1): 15-20

McCann KS. 2000. The diversity-stability debate. Nature 405: 228-233

Naeem S and S Li. 1997. Biodiversity enhances ecosystem reliability. Nature 390: 507-509

Negi JDS, D Shah, P Kukreti, M Negi, HS Basera, SK Kamboj and PS Chauhan. 2002. An ecological assessment of sal mortality in Uttaranchal. Annals of Forestry 10(2): 193-203

Pandey SK and RP Shukla. 1999. Plant diversity and community patterns along the disturbance gradient in sal (Shorea robusta Gaertn.). Current Science 77(6): 814-818

Paudel SG. 2003. Farmers' awareness of and attitude towards farmland conservation technologies in the hills of Nepal. Banko Janakari 13(1): 29-38

Polunin O and A Stainton. 2000. Flowers of the Himalaya [fourth impression]. New Delhi (India): Oxford University Press. $545 \mathrm{p}$

Rai SN, IC Dutta, S Haque, BB Khanal, JP Chaurasia and IP Indu. 1999. Ecology and growth of Shorea robusta in Central Nepal. In: P Mathema, IC Dutta, MK Bala and SN Adhikari (eds), Sustainable forest management. Proceedings of international seminar, 1998 Aug 31-Sept 2; Pokhara. Pokhara (Nepal): Institute of Forestry, Tribhuvan University. p 117-125

Rautiainen O. 1996. Regeneration status of sal (Shorea robusta Gaertn.f) in Bara district, Nepal. Banko Janakari 6(1): 26-32

RWEDP. 1997. Regional study on wood energy: Today and tomorrow in South Asia. Bangkok (Thailand): Food and Agriculture Organization (FAO), Regional Office for Asia and the Pacific. $167 \mathrm{p}$

Schulte-Bisping H, M Bredemier and F. Beese. 1999. Global availability of wood and energy supply from fuel wood and charcoal. Ambio. 28(7): 592-594

Shrestha DL. 2000. Present status of wood energy in Nepal. In: Woodfuel trade in Nepal. Proceeding of a national workshop; 1998 Aug 25-28; Dhulikhel, Nepal. Bangkok (Thailand): Food and Agriculture Organization (FAO), Regional Office for Asia and the Pacific. p 15-21

Shankar U. 2001. A case of higher tree diversity in a sal (Shorea robusta)dominated lowland forest of eastern Himalaya: Floristic composition, regeneration and conservation. Current Science 81 (7): 776-786

Stainton A. 1997. Flowers of the Himalaya: A Supplement. New Delhi (India): Oxford University Press. $72 \mathrm{p}+128$ plates

Valverde T and J Silvertown. 1997. Canopy closure rate and forest structure. Ecology 78(5): 1555-1562

Vetaas OR. 2000. The effect of environmental factors on the regeneration of Quercus semecarpifolia Sm. in central Himalaya, Nepal. Plant Ecology 146: 137-144

Zobel DB, PK Jha, NJ Behan and UKR Yadav. 1987. A practical manual for ecology. Kathmandu (Nepal): Ratna Book Distributors. $150 \mathrm{p}$ 